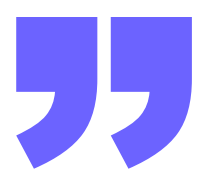

\title{
PERSUASIVE TECHNIQUE ANALYSIS OF JAKARTA POST DAILY E-PAPER
}

\author{
Made Linda Novionita ${ }^{1}$ I Gusti Agung Sri Rwa Jayantini², Ni Wayan \\ Suastini ${ }^{3}$ \\ 1,2,3English Study Program, Faculty of Foreign Languages, \\ Mahasaraswati Denpasar University, Jalan Kamboja No. 11A, Dangin \\ Puri Kangin Denpasar Utara, Bali 80236 Indonesia \\ lindanovionita2323@gmail.com¹, agung_srijayantini@unmas.ac.id², \\ suastini28@unmas.ac.id ${ }^{3}$
}

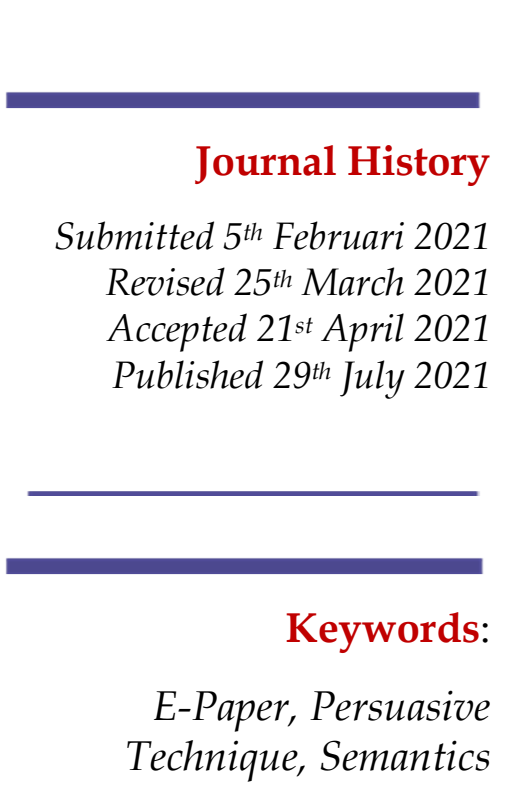

\begin{abstract}
In this era, the news is a medium to share the information and some newspaper companies had already made the E-Paper. There are some problems discussed in this article such as the type of persuasive technique and its function used in The Jakarta Post daily e-paper and meaning consists in the persuasive technique. The collected data were analyzed by applying descriptive qualitative method. In the analysis, persuasive language technique and its function were comprehensively analyzed based on theory from Walton (2005) and the meaning used theory from Leech (1981). There were seven types of persuasive language techniques found in The Jakarta Post daily e-paper. The use of adjective is a persuasive language technique that is often used in The Jakarta Post's news that published on 21st September 2020 until 25th November 2020.
\end{abstract}

\section{INTRODUCTION}

Information is the most significant thing in daily activities as people need the information to know the event around them. An information about lifestyle, politic, cultural, economic, etc. People able to get an update information from communication to each other or a news that share thru offline and online tools. News is a new event selected by journalistic and anything timely that interests several readers (Blayer, 1916). Nowadays, news had already provided in more modern and easy to be accessed by the reader. Internet is one of the simplest way to get the news. Information on digital media become a significant need by the social community that make the number of new online news portal raises (Iswara \& Bisena, 2020). EPaper is an online newspaper published as an electronic document on a 
computer network or a print newspaper's digital version. The phenomenon uses a persuasive technique in the online newspaper to ask people read some update information from newspapers. The use of E-paper is fascinating because there is high mobility among us, making people unable to have their own quality time for themselves (Hennita, Prisylia \& Safffira, 2020).

The persuasive technique defines as a study of language which can make an act to persuade or to perform an action from others in psychology side of people, therefore people will do something based on what the persuader deliver in verbal and non-verbal (Walton, 2005; Alam, 2020). The use of persuasive technique to deliver and campaign information, also language used can influence the people' ideas, behavior, value and expected to accept the emotions of the readers or the audiences (Iswara \& Bisena, 2020; Situmeang \& Sugianto, 2017; Rudito \& Anita, 2020). The newspaper, persuasive technique used to attract and behave the people to read the news and look the fact, therefore people will persuade to do something that mentions in the news after they read and understand the meaning what the author would like to share to the number of people. Persuasive communication which is using online media such as computer technology or internet basically, same as face to face communication however it is using media to help communication process with a distance in high mobility of people in this era (Rudito \& Anita, 2020; Putri, Lukmantoro, Dwiningtyas, et al, 2015; Alam, 2020; Purba, 2017). Sometimes newspaper contains of business advertorial which persuasive technique used in this case. There are some techniques to persuade readers proposed by Walton (2005) such as adjectives, adverbs, alliteration, colloquial language, connotation, and repetition.

The main issue was to know the use of persuasive technique in our daily activities. One of them is in newspaper that people read every day. This article is focused on discussing type of persuasive technique used in The Jakarta Post daily e-paper and the meaning found in the persuasive technique used in the E-paper. The discussion about the persuasive technique used in the news in literature is still limited as persuasive technique often used in the advertisement to attract the customer to buy or use the product or service in their point of view (Wahyuni, 2014; Hennita, Prisylia \& Saffira, 2020) in other ways, persuasive technique also found in other aspects such as academic, campaign, and motivation. Examined the use of persuasive language in advertorial business in the online newspaper. Persuasive language looks tricky and powerful in arguments and need to be analyzed with logical also critical thinking (Iswara \& Bisena, 2020), therefore to support this research, the writer use a theory of persuasive techniques that divided persuasive technique into eight types namely 
adjectives, adverbs, alliteration, rhetorical question, colloquial, connotation, description, and repetition.

The opinion of someone also sometimes used in negative way, it makes use persuasive technique can be a risk if the receiver has another perception what the communicator want to say especially the information that shared on digital media is one of the triggers of hoax easily produced (Iswara \& Bisena, 2020). The last is giving the conclusion of the statement. The receiver needs the conclusion to know what is the result of someone statement. Therefore from the process above, understanding the meaning is a significant thing in positively persuade someone There is a close connection between a language used and processed its meaning and the choice of words able to distinguish the meaning of the sentence (Komar, 2015; Kubro \& Suyitno, 2019). Semantics is central to the study of communication; and as communication becomes a crucial factor in social organization, the need to understand it becomes more pressing. Semantic also the study of human mind or thought processes, cognition, conceptualization. (Leech, 1981) divided meaning into seven types such as conceptual meaning, connotative meaning, social and affective meaning, reflected and collocative meaning, associative meaning, thematic meaning. However, in this case conceptual meaning and connotative meaning are focused to be discussed to understanding the meaning in the newspaper.

\section{METHODS}

Descriptive qualitative method was applied to present the data that the data show in the form of sentence and table to show the persuasive technique used in The Jakarta Post. Then, describe it more precisely to make the data easier to be understood by description text. Before analyzing the news, the first step was studied, understood, selected the data from The Jakarta Post website and collected the data in the form of screen shoot in every data contained the persuasive technique. After collected the data, it was analyzed based on persuasive technique and its function related to the theory by Walton (2005) and analyzed the conceptual or connotative meaning of persuasive technique used related to the theory by Leech (1981) to find out the conclusion of the research. The author use persuasive technique theory by Walton (2005) to analyze technique used in the newspaper. The technique are adjectives, adverbs, alliteration, connotative, rhetorical question, colloquial language, and repetition. Therefore, in analyzing persuasive technique, the persuasive function applied in the newspaper that Walton explained as well.

Semantic analysis used theory from Leech to understand that the meaning consists of the newspaper's persuasive technique. Leech divided meaning into seven, however, the meaning to be analyzed only focus to the 
conceptual meaning which are the literal meaning and connotative meaning that could be associated to another thing. Understanding the meaning is a must to interpret what the author wants to share the information to the number or people to avoid the misunderstanding and make the news evidence to get an excellent reputation. This research aims to find the use of persuasive technique and implementation of how to persuade people to read the news and get knowledge from the information that shared from the news. This research also expected to develop knowledge about persuasive technique that represented theory by Walton (2005) and how to understand the meaning of the news to avoid bad image caused global information represented by Leech (1981). Besides that, this research aims to provide a reference to other who are studying literature to analyze persuasive technique in different objects.

\section{RESULTS AND DISCUSSION}

\section{RESULT}

This article aims to find out persuasive technique and its meaning used in The Jakarta Post E-Paper. In analyzing the data, the writer focuses on analyzing the type of persuasive technique, function and meaning consists in The Jakarta Post E-Paper. There are seven types of persuasive technique used in the data such as adjective, adverbs, alliteration, rhetorical question, connotative, colloquial language, and repetition and describe the conceptual and connotative meaning based on the data. The result found that in 77 data collected, adjectives technique is mostly used by the author to hyperbole the conceptual meaning consists in the headline. This technique makes the reader curious to what they read on the articles.

\section{DISCUSSION}

\section{Adjectives}

Adjective is one of persuasive technique used by The Jakarta Post online newspaper. Adjectives describe words to something in a particular way. Also, adjectives are used to identify and quantify individual people or characteristics of something, which are adjectives often found before noun or pronoun. The writer found some adjectives as persuasive technique used in the data source.

Belgium uses a giant vacuum cleaner to remove plastic from nature reserve (The Jakarta Post, October 12th, 2020)

An adjective is used in the sentence. The adjective in the sentence to modify the noun vacuum cleaner to change its quality. The word "giant" as an adjective in the sentence above, "giant" means very large; much larger or important than similar things. The conceptual meaning consists of the data, 
"giant vacuum cleaner" based on theory Leech (1981), conceptually "giant" means very big, large, and more important than others. In this context, the news would like to send the information that there is a new innovation to solve environment problem. Giant vacuum cleaner on the sentence use to clean plastic and keep the environment around us due to plastics is difficult to destroy naturally and needs more than 100 years. The news above tells everyone that there is a new technology to solve the problem and an adjective used to reinforce the meaning of the context to attract the customers. The adjective technique used in the data to persuade the reader that something launched in the news is very interested to put in the news as the conceptual meaning, the tools are remarkable and maybe the first time. Therefore, the reader will be interested in reading the news on how it impacts real life and the information that was sending through the news as motivation to do something or increase knowledge. Therefore, the author used adjective technique to make an image of something as new innovation or advertise the product. The use of adjective here also to ask people keep their environment from plastic as a big problem and need a new technology to reduce it as well.

\section{Adverbs}

An adverb is one of the persuasive language technique used in The Jakarta Post's news headline. Adverbs are the word to change or qualify the meaning of a verb, adjectives, a clause of another adverb, and any other type of words, exception determiner. The data source mostly used adverbs of manner as the persuasive technique. Here is data contain with adverbs in The Jakarta Post.

Speak softly and scatter fewer coronavirus particles, say researcher (The Jakarta Post, November 25th 2020)

The data above is used adverb in the sentence, it was found the word "softly" as a persuasive technique used which is classified as an adverb of manner, due to it qualify the meaning of verb or an action in the sentence. "softly" means something that is not roughly and it could be describe something that has low volume. Based on Leech (1981) theory, the conceptual meaning of softly means to minimize and make it slow. We need to stop speak too loud that make the small particulars out from mouth that might be contained with virus. The data shows a campaign and adverbs technique occurred to make it a strong statement that ensures that is one thing that people need to do start from now. From the news headline, the reader will ask the factors and interest in reading the news and asking people to stop the spreaders from the small thing that can stop the corona virus. 


\section{Alliteration}

Alliteration used in The Jakarta Post's news headline as the persuasive technique. This technique refers to repeated two or more consonant sounds in the stress syllable. The indicator is used the first letter of the word are same or have the same sound with another word in a phrase. Business and advertisement are often used alliteration to get the people interested due to make phrase memorable and fun to read it.

Govt seeks to curb virus with targeted, testing, tracking (The Jakarta Post, October $15^{\text {th }}, 2020$ )

Alliteration technique is used in the sentence because it was found words "targeted, testing, tracking". There are same repetition consonant sound on the first letter " $\mathrm{T}$ " in each words, also those three words have same stress syllables such as 'tar-get-ed, 'test-ing, 'track-ing as the indicators. The data can be described as a way to campaign something. The conceptual meaning of "targeted" means straightforward to the point, "testing" means take the measure of quality or to find out how the condition of something, and "tracking" means find the target. In this sentence "targeted, testing, tracking" means three steps that used by the government to prevent virus spreads. The technique used in the sentence to share a campaign to prevent the virus. It was expected to persuade people to find what it is and then do it after making people remember the process and open mindset about the virus is very dangerous if it still spreads around us.

\section{Rhetorical Question}

Another one of the Jakarta Post's news headline's persuasive technique is a rhetorical question. The technique is used a question that did not need to be answered because the answer makes obvious. Rhetorical question give a feels to the reader as though they are being addressed directly by the writer. It is also used to bring the reader or hearer to the conclusion and it is used to reveal the point rather than to get an answer.

Dine in or take out?: officials debate how to curb Covid-19 (The Jakarta Post, September 30th 2020)

Rhetorical question technique is used in the sentence. It was found a question "dine-in or take out?" as rhetorical question technique used in the news headline that no need to be answered by the reader. A question "dinein or take out?" means someone's opinion about something which in this context to an activity to find something new to stop the virus. The rhetorical question above is to ask people to choose during pandemic situations; however, it is supposed to persuade someone to try something different, which is better. People can do it during work from home instead of only focus on the pandemic. In the sentence above, conceptual meaning consists of a question "dine-in or take out?" means how to rationalize which one is 
better to stop the corona virus's spread. However, from the data "dine in or take out?" as someone's comparison during the pandemic situation. The used of rhetorical question here to persuade someone stay at home as one of the ways to stop the chain of virus spreads. It is more efficient if we do something that we can do to help the government minimize the problem. Then, the sentence above is a campaign to inform us that it is better to stay at home longer than remain outside during the pandemic.

What's on your plate? A sneak peek into the making of vegan. (The Jakarta Post.com, September 21 1 , 2020)

The rhetorical question is used in the sentence as one of the persuasive technique. There is a question "what's on your plate?" does not need to be answered however to emphasize the reader's point of view about the foods. The technique is to described someone's feels disagree about junk food which is mention it in the sentence on your plate. Disagreement shows on the question what's, which from the question the author tried to persuade the reader start to eat healthy foods instead of junk food. The connotative meaning consists in "what's on your plate?" in the sentence can be associated as unhealthy food. In conceptually, question above represent as a food on a plate however after the rhetorical question there is a sentence to clear the meaning of question. Rhetorical question above is kind of teasing, is your daily food healthy enough for your body or not and the news is being persuasive in order to give the information how to persuade the people mindset to start eat the healthy food one of them is vegan which show on last sentence.

\section{Colloquial language}

Colloquial language is one of the persuasive language technique used in The Jakarta Post's news headline. Colloquial language sometimes as everyday language shown by the words that realistic and practical and makes themselves seem down-to-earth. Here is colloquial language found in the data source.

You're gonna need a bigger museum 'jaws' share installed. (The Jakarta Post, November 25th 2020 )

Colloquial language can be seen in the sentence above as one of the persuasive features. Colloquial language was used in the sentence, there is a word "gonna". Gonna came from "going to" and people using gonna to make it down-to-earth which is supposed to make easier communicate with the others in a friendly way. Colloquial technique usually will use on informal news such as someone's opinion. The conceptual meaning in the sentence of the word "gonna" means that someone will do something. In this context, the use word gonna to show something that will happen or plan to do it. Therefore, the author used colloquial language technique to 
be more attractive to the reader, try to attract people to read news, and look not always bored, only focusing on formal language in formal news. This is one of the author's persuasive techniques to make the news more attractive, innovative, and easier receive to the reader. The target is mature and the teenagers that more popular use colloquial as their daily language.

\section{Connotation}

Persuasive language technique also uses connotation to attract people curious to read the news. A connotation is a word that the ideas or feelings associated with another particular word. Connotation refers to the feelings and emotions, or cultural association with that word rather than its dictionary definition or the real meaning of a specific word. Below are some data that consist of connotation technique.

Washington zoo panda named 'Little Miracle' (The Jakarta Post, November $25^{\text {th }}, 2020$ )

The connotative technique is used in the sentence because it was found phrase "little miracle" in the news headline. The term "little miracle" associated to a place where a wonderful place like heaven. In the news headline, the author used connotative meaning to create image view of the reader and the reader able to emphasize its meaning. This technique was used to persuade the reader to read the news by using a connotation to draw an idea of something. Conceptually, the connotation meaning of "little miracle" are words "little" can be describe as a small place where it looks cute. The word "miracle" describe as a magic. Moreover, little miracle associated to a beautiful place like in the heaven. In this context, a small place is panda captivity. "little miracle" here describes as a zoo that keeps some of cute panda there. The author would like to inform it by using the connotation technique not to send the information straightforwardly. The author used another word in a similar meaning and tried to make an image of something. The news above to persuade people to keep the animal especially rare animal in a good and comfort place for them which is influenced good behave between us as mortal.

Apple buys 'Cherry' from Avangers: End game directors. (The Jakarta Post, September $26^{\text {th }}, 2020$ )

The connotative technique used in the sentence is found in the news because there is a word "cherry". The word "cheery" is a small sweet fruit that usually has red, green, or black color and it used as garnish of foods and beverages. In this context, "cherry" is associated to a person. In order to make the news headline more attractive and innovative, the author, used comparison between two fruits those are apple and cherry which one of them is not used their own real meaning to build curiosity of the reader 
therefore the reader will interest to read the news to know what the meaning and full information that the author would like to inform. In the sentence above connotative meaning of "cherry" means that the best actor of Avangers has contracted by Apple which the word apple here is the name of a well-known brand company to cooperate with them. The actor associated with "cherry" because if Apple built a mutualism cooperation with this actor, they will get its sweetness or associated a sweetness of its fruit to revenue in this context. Therefore, the author compares two fruits to make the author's report news more innovative. The reader attract to read the news and use persuasive technique as the marketing strategy because Apple used a famous actor to advertise their product, and people will interest to buy the products.

\section{Repetition}

Persuasive language technique used in The Jakarta Post's is repetition. Repetition is often repeat the words and phrases a few times to make an idea clearer and can be used to reinforce an argument and drive home the message to the reader to agree with an issue. Here is data that consist with repetition technique found in the data source.

No rallies, no concert: Govt plans for restrict crowds during regional races. (The Jakarta Post, September $26^{\text {th }}, 2020$ )

Repetition is used in the sentence as one of the persuasive technique. The repetition word " $n o$ " was found in the data as the repetition technique indicators. The word "no" means something do not to do or nothing happens. In above news headline repetition "no" used by the author to mention some impossible events, the author stresses it to attract people's sympathetic which the topic will be read in the full news. In the sentence above, there is conceptual meaning of using " $n o$ " means there is no event held during the pandemic. Therefore the author used repetition technique to reinforce people's belief and attitudes for the new regulation to stay at home during pandemic situations as the government avoids crowds to prevent the spreads of corona virus, repeat "no" is to stress the rules from government that the people should follow it. The persuasive technique also used as campaign tools to spread the new habit that people need to do.

\section{CONCLUSION}

The discussion above can conclude that the use of persuasive technique and its function is significant in the news as a tool to spread out the information worldwide. Persuasive language technique presented in the data is found at the beginning of the sentence and in the middle or at the end of the news headline. It was found seven types of persuasive technique in the data. Based on the analysis, it can be concluded that 
conceptual meaning is mostly used in the news headline. The conceptual meaning used to make evidence news based on the fact, informative news, easier to be understood by the reader, and send straightforward meaning to the reader. The news headline consists of conceptual meaning presented literal meaning of the sentence which the main news will same as the headline. However, sometimes the author uses connotative meaning in the news headline to attract people read the news and make headlines to increase the readers' number without exaggerating the meaning. The meaning consist of the persuasive technique also needs to be understood well by the reader. Sometimes there will be pro and contra because of different interpretation meaning in the news.

\section{REFERENCES}

Aditama, Madya Giri. (2016). Persuasion in International Journals: Pramatics Analysis.

http:/ / eprints.ums.ac.id/40530/1/ARTIKEL\%20PUBLIKASI\%20IL MIAH.pdf. Downloaded on February 10th 2020.11 .48 a.m WITA.

Alam, Sukma. (2020). “Peran Influencer Sebagai Komunikasi Persuasif Untuk Pencegahan COVID-19". Jurnal Spektrum Komunikasi Vol. 8 No. 2 December 2020.

Berliana, Giasinta. (2019). Kiprah The Jakarta Post Daring dalam Era Media Baru. https://www.kompasiana.com/. Retrieved September 2, 2019, 10.16 WITA

Blayer, Willard Grosvenor. (1916). Types of News Writing. United States: The Riverside Press Cambridge

Derin, Tatum., Nursafira, M.S., Yudar, R.S., et al. (2020). “Persuasive Communication: What Do Existing literature Tells Us About Persuasive". UTAMAX: The journal of ultimate research and trends in education Vol. 2 No. 1 March 2020.

Ginting, Risky., Sili, Surya., Setyowaty, Ririn. (2019). “ The Persuasive Technique Types in Donald Trump's Public Speaking". Jurnal Ilmu Budaya. Vol. 3 No. 2 April 2019.

Hemeren, Lars. (1999). English for Sale: A Study of Advertising. Lund: University Press

Hennita, Gisela., Prisylia, M.E., Saffira, Violita. (2020). "Analisis Komunikasi Persuasif Pada Akun Instagram Frelynshop Dalam Meningkatkan Brand Image". Medialog: Jurnal Ilmu Komunikasi Vol. 3 No. 2 August 2020 
Huang, Danyan. (2019). “A Study on Persuasive Language in Personal Selling". International Journal English Linguistics Vol. 9 No. 2 March 2019.

Iswara, A,A., Bisena, K,A. (2020). “Manipulation and Persuasion Through Language Features In Fake News". RETORIKA: Jurnal Ilmu Budaya. Vol. 6 No. 1 April 2020.

Kubro, Rizkia A., Suyitno, Imam. (2019). "Persuasive Language in Advertisement Discourses (Business Advertorial Analysis)". ISLLAC: Journal of Intensive Studies on Language, Literature, Art, and Culture. Vol. 3 No. 2 December 2019.

Kurniawan, Ridho., Novita, Yulatri. (2020). “Tindak Tutur Persuasif Pedagang Kaki Lima di Pasar Kaget Gelora Haji Agus Salim Padang". Jurnal Muara Pendidikan Vol. 5 No. 1 June 2020.

Leech, Geoffrey. (1981). Semantics The Study of Meaning Second Edition. Great Britain: Penguin Books

Oxford. (2015). Oxford Advanced Learner's Dictionary: Ninth Edition. New York: Oxford University Press

Purba, D.A. (2017). "Persuasive Strategies in Woman Cosmetics Advertisement of Skin Whitening Product on Television Commercial".

http:/ /jurnal.unimed.ac/id/2012/index.php/jalu/article/downloa d/7596/6448. Downloaded on February 11 $11^{\text {th }}, 2020.8 .55$ p.m WITA

Putri, F. I., Lukmantoro, T., Dwiningtyas, H., et al. (2015). “ Teknik Persuasif Dalam Media Sosial ( Studi Analisis Isi Kualitatif Pada Akun Mentor Parenting Ayah Edy di Yourtube). Jurnal Ilmu Komunikasi Vol. 2 No. 2 April 2015.

Rudito, Yeremia., Anita. (2020). “Persuasive Strategies Used In Burger King's Instagram Post's Caption". Journal of Language and Literature Vol. 8 No. 1 June 2020.

Schmidt, R, and Kess Joseph F. (1986). Persuasive Language in Advertising and Televangelism: Discourse Analysis of Persuasive Language. Amsterdam: University of Victoria

Situmeang, I.V., Sugianto, A. S. (2017). “The Identification of Persuasive Message Campaign Wonderful Indonesia 2015". Jurnal ASPIKOM Vol. 3 No. 3 July 2017.

Widiastutik, S. (2020). "Strategi Persuasif Dalam Sales Promotion Dengan Media Outdoor Ad: Studi Kasus Bahasa Persuasif Pedagang Kaki Lima di Denpasar Selatan". JSHP: Jurnal Sosial Humaniora dan Pendidikan Vol. 5 No.1 June 2020. 
Wahyuni, Elli S. (2017). “The Strategy of Using Persuasive Essay in English for Medical Academic Writing". JHS: Jurnal Social Humaniora. Vol. 7 No. 1 June 2017.

Walton, Douglas.(2005). Deceptive Arguments Containing Persuasive Language and Persuasive Definition. Canada: University of Winnipeg

Walton,Douglas. (2007) .Media Argumentation Dialectic, Persuasion, and Rethoric. United States: Cambridge University Press 